\title{
Electrical resistivity and Ground Penetrating Radar for the characterisation of the internal architecture of Quaternary sediments in the Midlands of Ireland
}

\author{
Xavier M. Pellicer ${ }^{\mathrm{a}, *}$, Paul Gibson ${ }^{\mathrm{b}}$ \\ a Geological Survey of Ireland, Beggars Bush, Haddington Road, Dublin 4, Ireland \\ ${ }^{\mathrm{b}}$ Environmental Geophysics Unit, Department of Geography, National University of Ireland, Maynooth, Co. Kildare, Ireland
}

\section{A R T I C L E I N F O}

Article history:

Received 28 January 2011

Accepted 14 September 2011

Available online 25 September 2011

\section{Keywords:}

Glacial

Electrical Resistivity Tomography

GPR

Near-surface

Ireland

\begin{abstract}
A B S T R A C T
Geophysical techniques Electrical Resistivity Tomography (ERT) and Ground Penetrating Radar (GPR) supported by traditional field methods are used for the geological mapping, description and interpretation of Quaternary unconsolidated sediments in a site located in the Midlands of Ireland. The site comprises a broad range of glacial and postglacial sediments (diamicton, esker sand and gravel, glaciolacustrine sand, glaciolacustrine silt/clay and peat). Preliminary fieldwork comprising, geomorphological mapping, lithostratigraphic analysis of exposures and borehole drilling and laboratory testing encompassing particle size distribution analysis were carried out to broadly characterise the geology of the study area. These data aided locating the geophysical profiles and supported the geophysical data interpretation. Five GPR radargrams were collected and permitted depicting the subsurface internal architecture within low conductivity unconsolidated sediments and aided to the classification and characterisation of sedimentological and deformational structures. Four ERT profiles allowed the depth to bedrock to be determined and lithological classification of the sediments. The use of these geophysical techniques in combination with geotechnical and geological data allowed (i) the determination of the lithological composition and detailed internal architecture of the subsurface, (ii) the characterisation and description of the geology of the site and (iii) understanding the depositional processes acting in the area during ice withdrawal. Diamicton and esker gravels were deposited subglacially by an ice sheet withdrawing westwards; glaciolacustrine sediments located along the south margin of the esker ridge were laid down in an ice marginal environment as a subaqueous fan composed of silt, sand and gravel, and as distal deposits composed of silt and clay in the lower ground area between the fan and the esker ridge. Peat developed during postglacial times and was partially cut away by anthropogenic action at a later stage.
\end{abstract}

(c) 2011 Elsevier B.V. All rights reserved.

\section{Introduction}

Although sediments laid down during the Quaternary period cover more than $90 \%$ of the Irish landscape, traditional geomorphological mapping and outcrop analysis are often constrained by the limited number of exposures available and poor morphological expression. In addition, geotechnical investigations are expensive and only provide sparse point data for Quaternary deposits which often show high sedimentological, lithological and tectonic variability within very short distances. Electrical Resistivity Tomography (ERT) and Ground Penetrating Radar (GPR) geophysical techniques have been widely used in the past for Quaternary deposit lithological and sedimentological characterisation ( ERT - e.g. Baines et al., 2002; Kilner et al., 2005; Wisen et al., 2005; GPR - e.g. Bakker and van der Meer, 2003; Smith and Jol, 1992; Trafford, 2009; Ulriksen, 1982). The integration of electrical and electromagnetic geophysical techniques as complementary tools

\footnotetext{
* Corresponding author. Tel.: + 35334638762695.

E-mail address: xavimir@yahoo.com (X.M. Pellicer).
}

for unconsolidated sediment characterisation has been widely explored during the last decade in fields such as: describing peatland areas (Comas et al., 2004; Kittredge et al., 2008; Slater and Reeve, 2002); 3D visualisation of active faults (Vanneste et al., 2008); mapping river terrace deposits (Hirsch et al., 2008); characterising shallow aquifers (Doetsch et al., 2011; Turesson, 2006); recognising groundwater flow through glacial sediments (McClymont et al., 2011); and investigating the influence of glacial sediments on the development of peatlands (Comas et al., 2011). However, the combination of these techniques as unconsolidated sediment mapping tools has not been explored in Ireland. In order to explore such geological mapping approach, a site located in the Irish Midlands encompassing a broad range of geomorphological features presenting a variety of sedimentological and lithological settings was selected. A preliminary Quaternary geology investigation encompassing geomorphological mapping, exposure recording and geotechnical investigation was carried out previous to the geophysical surveys. It is finally intended to integrate the geophysical techniques ERT and GPR in the Quaternary geology mapping process. The results obtained from geophysical surveys and traditional mapping techniques (e.g. borehole and exposure data) are integrated 
in order to refine the interpretation of the collected geophysical datasets, describe the glacial and postglacial sediments encountered in the area and reconstruct the glacial history of the site.

\section{Geographical and geological setting}

The study area is located within a lowland region of the Irish Midlands flanked to the north by drumlin/crag and tail landscape, to the east by the watershed between the Shannon and the Barrow basins, to the south by the Slieve Bloom Mountains and by the Shannon River to the west (Fig. 1a). This region is dominated by a range of glacial and postglacial sediments. The most striking features in the region are several large ridges running west to east in the area north and south of Tullamore and interpreted by Farrington and Synge (1970) as esker ridges composed of subaqueous fans deposited sequentially from subglacial conduits at the ice margin. The model of deglaciation during Weichselian times presented by Warren (1992) envisaged two main ice centres: the Northern Dome (centred on the north Midlands) and the Central Dome (centred in Connemara Mountains), retreating north-westwards and westwards respectively. Such model was recently refined by cosmogenic isotope dating (Ballantyne et al., $2006,2007,2008$ ) and by remote sensing regional geomorphological mapping (Greenwood and Clark, 2009a,b). Sedimentological analysis carried out in the Irish Midlands (van der Meer and Warren, 1997) on late glacial clays in lacustrine basins shows sedimentation of rhythmites and clays in an unstable environment and the presence of floating ice in a glacial lake environment. Moreover, glaciolacustrine deposits described in the Irish Midlands (Delaney, 2002) envisaged a glacial lake (Glacial Lake Riada) with a maximum water table at $92 \mathrm{~m}$ ordnance datum (OD) in the study area during deglaciation times. This is supported by mushroom stones mapped by Feehan and Dunne (2003) indicating presence of long term shorelines of a glacial or post glacial lake in the Irish Midlands and by varved sediments deposited during Late Weichselian times (22-10 Ka BP) in a proglacial lake environment (Delaney, 2008).

The site is located $9 \mathrm{~km}$ east-southeast of Tullamore Town at $7^{\circ} 23^{\prime}$ $40^{\prime \prime} \mathrm{W}, 53^{\circ} 15^{\prime} 10^{\prime \prime} \mathrm{N}$ - Irish National Grid (ING) E240700, N222900, it covers an area of $0.25 \mathrm{~km}^{2}$ and it is composed of unconsolidated sediments underlain by Lower Carbonifereous Limestone (Hitzman, 1992). A section of the Geashill Esker runs along the site's northern margin in a west-southwest to east-northeast direction (Pellicer, 2010). It reaches a maximum height of 3-4 m relative to the surrounding landscape and is between 20 and $50 \mathrm{~m}$ wide. The esker is bounded to the north by a low lying landscape dominated by peat deposits extending northwards for a few kilometres and to the south by an east northeast-west southwest flat stretch of poorly-drained low ground dominated by silts and clays and blanketed by a thin coating of peat. This low lying stretch is bounded to the south by a well drained, flat-topped elongated fan running east-west for approximately $2 \mathrm{~km}$, reaching a maximum height of $10 \mathrm{~m}$ above the surrounding landscape and encompassing widths of $200-450 \mathrm{~m}$. A maximum height of $72 \mathrm{~m}$ OD is reached by this feature within the site. The feature is bounded to the south by poorly drained low ground composed of diamicton. The main geomorphological features and the dominant sediment types recorded in the study area are illustrated in Fig. 1.

\section{Methodology}

Sedimentological characterisation of two exposures recorded in the site was based on the lithofacies coding scheme of Benn and Evans (1998). A geotechnical investigation was carried out using a continuous flight auger which yielded data from eight boreholes. Particle size distribution analysis was carried out by Metlab International Ltd. at the minimum standards accepted by the BS EN ISO 22476-2:2005 (2006) on 26 samples collected from the boreholes. The samples were subsequently classified under the Folk (1954) classification scheme. These data permitted differentiating between the main lithological types occurring in the area and establishing a relationship between ERT data and lithological classes.

Electrical Resistivity Tomography (ERT) data were collected using a Campus Geopulse system with 25 electrodes using the WennerSchlumberger array. This array gathers 157 resistivity measurements for each profile to create a pseudosection. Data collected included a
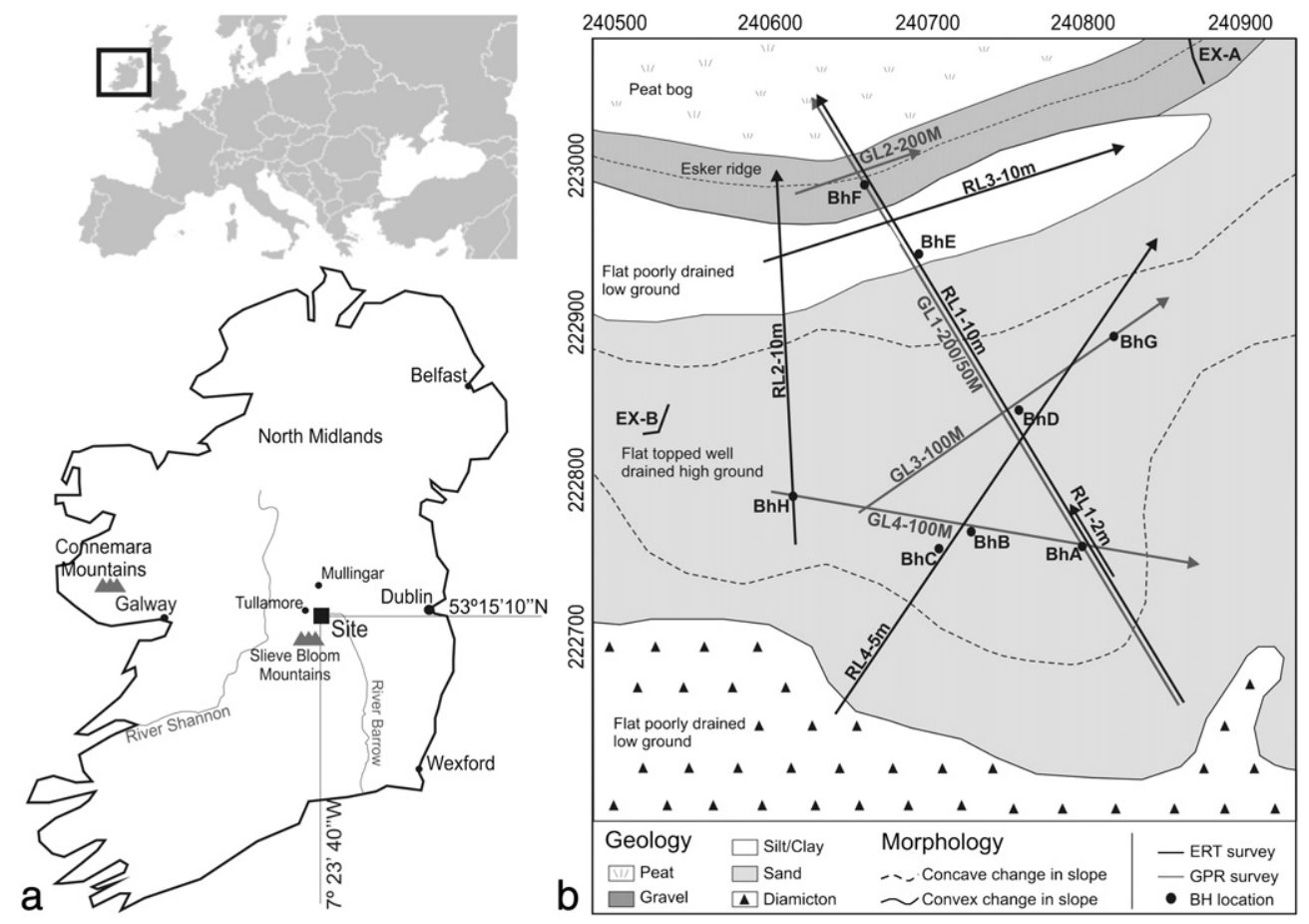

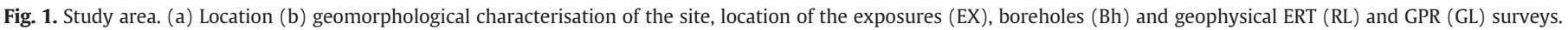


profile at $2 \mathrm{~m}$, a profile at $5 \mathrm{~m}$ and three profiles at $10 \mathrm{~m}$ spacing, encompassing lengths of $48 \mathrm{~m}, 120 \mathrm{~m}$ and $240 \mathrm{~m}$, respectively. Several steps were followed to generate a model from the pseudosection. Data were edited when necessary, the editing stage encompassed: (a) merging of ERT profiles collected inline (b) reversing of some datasets in order to present the data in a consistent direction and (c) topographic correction of all the profiles with altitudinal data extracted from the Ordnance Survey of Ireland $10 \mathrm{~m}$ pixel size Digital Elevation Model (DEM). All datasets were inverted using RES2DINV software (Loke and Barker, 1996). The software generates a calculated model of the pseudosection from the inverted model, the Root Mean Square (RMS) error between the calculated and the measured pseudosection is computed. A least-squares algorithm is used to reduce the RMS error between the measured and the calculated apparent resistivity in an iterative mode. Two inversion methods are available in the software package, the Gauss-Newton smoothness constrained least-squares (deGroot-Hedlin and Constable, 1990) and Gauss-Newton robust model constrained (Claerbout and Muir, 1973), both routines were tested for data inversion, as a general rule, features depicted for both methods can be considered real (Loke, 2001). Interpretation of the models was based on the resistivity range of some geological materials presented by several researchers (Guerin et al., 2004; Palacky, 1987; Reynolds, 1997) and the data obtained from geological mapping and geotechnical investigation carried out in the site.

Ground Penetrating Radar (GPR) data were collected using a Pulse EKKO system with a $400 \mathrm{~V}$ transmitter, perpendicular broadside antenna orientation in common offset step mode. $50 \mathrm{MHz}, 100 \mathrm{MHz}$ and $200 \mathrm{MHz}$ antenna frequencies were employed with the following settings: (i) $200 \mathrm{MHz}-0.5 \mathrm{~m}$ antenna separation, $0.1 \mathrm{~m}$ step size and $150 \mathrm{~ns}$ time window; (ii) $100 \mathrm{MHz}-1 \mathrm{~m}$ antenna separation, $0.25 \mathrm{~m}$ step size and $250 \mathrm{~ns}$ time window; (iii) $50 \mathrm{MHz}-2$ m antenna separation, $0.5 \mathrm{~m}$ step size and $300 \mathrm{~ns}$ time window. Two profiles were collected using a $200 \mathrm{MHz}$ antenna, two using a $100 \mathrm{MHz}$ and one using the $50 \mathrm{MHz}$. Furthermore, two common midpoint surveys (CMP) were carried out in the fan area to estimate subsurface velocities. All GPR data were processed using the EkkoView Deluxe software package. The radargrams were previously edited by removing unwanted traces and merging and reversing profiles when required. Data was systematically processed as follows: (i) time zero adjustment; (ii) low frequency removal ('dewow') using a window width of one pulse-width of the nominal frequency; (iii) application of an automatic gain control (AGC); (iv) migration of the data with the 2D F-K migration method using the Stolt (1978) algorithm with a constant velocity and; (v) topographic correction. The velocity used for migration and topographic correction of the radargrams was estimated from the CMP profiles and individually for each profile by means of hyperbolae velocity calibration (Neal, 2004). GPR data interpretation was based on the concept of radar stratigraphy developed through the last two decades (e.g. Jol and Bristow, 2003; Jol and Smith, 1991; Moorman et al., 2003; Neal, 2004; Neal et al., 2002; Smith and Jol, 1995). Neal et al. (2002) introduced and defined the concepts of radar surfaces, radar packages and radar facies. A series of reflection profiles, based on their continuity, shape, dip and relationship to each other, was devised by the authors (Fig. 2). A coding scheme for radar surfaces and radar facies modified from Neal (2004) allowed the creation of a relative chronology within each radargram as well as with adjacent ones. The proposed coding system (Fig. 2) differentiates between radar surfaces and radar facies with subgroups for each category representing the potential situations presented by glacial, glaciofluvial, glaciolacustrine and postglacial sediments existing in the site. Reflectors within the profiles not directly related to sediment deposition (e.g. water table, faulting, hyperbolae derived from point features, noise... ) were also illustrated and described. Sedimentological interpretation was based on visual analysis of raw and filtered radargrams and it was supported by knowledge of the regional geology and geotechnical and geomorphological data.

\section{Results}

\subsection{Geological and geotechnical surveys}

Sediments recorded in two exposures (see Fig. 1b for location) were classified by the lithofacies coding scheme from Benn and Evans (1998). A 3-4 m high outcrop (EX-A) located along the esker ridge is dominated by crudely bedded matrix supported cobble/ boulder gravel (Bmg) with beds dipping $15-20^{\circ}$ north with a fine to medium sand matrix. A $2 \mathrm{~m}$ long lens of laminated silts and clays (Fld) occurs within the beds. These sediments are draped by a thin coating $(0-2 \mathrm{~m})$ of diamicton (Dmm), thickening towards the edges of the ridge and thinner on the ridge-top. The second exposure (EX-B) near the southern margin of the fan is dominated by interstratified sand and gravel. Sand (Sd) is fine to very fine with some silt component; bedding is deformed. Coarser material is mainly deposited as trough cross-bedded matrix supported medium to coarse gravel and as individual clast supported gravel beds. Characterisation of the eight boreholes (see Fig. 1b for location) is based on particle size distribution analysis carried out on 26 samples and subsequent lithological classification under Folk's (1954) scheme (Fig. 3). Boreholes BhA, BhB, BhC, $\mathrm{BhD}, \mathrm{BhG}$ and $\mathrm{BhH}$ are located on the fan (Fig. 1), in general terms, these boreholes present interstratified sand and gravel coarsening westwards underlain by diamicton at depths greater than 8 to $12 \mathrm{~m}$ : $\mathrm{BhA}$ is dominated by gravelly muddy sand overlying slightly gravelly muddy sand/sandy mud; BhB encompasses gravelly muddy sand overlying gravelly sandy mud; BhC presents muddy sandy gravel overlain by slightly gravelly muddy sand and underlain by gravelly sandy silt; BhD shows gravelly mud underlying slightly gravelly muddy sand and overlying gravelly silty sand; BhG is composed of silty sand overlying gravelly muddy sand; BhH is dominated by gravelly sand overlain and underlain by gravelly muddy sand. BhE is located along the contact between the lacustrine flat and the fan and shows slightly gravelly sandy mud overlain by a thin coating of peat and underlain by gravelly sandy silt. BhF was drilled on top of the esker ridge; the top $4 \mathrm{~m}$ are dominated by muddy sandy gravel with silty sandy matrix, no recovery from 4 to $10 \mathrm{~m}$ and gravelly mud from 10 to $11.5 \mathrm{~m}$. The borehole logs and sample descriptions based on Folk (1954) classification scheme are presented in Fig. 3; the layers recorded for each borehole log are generalised to the dominant lithology.

\subsection{Geophysical surveys}

\subsubsection{ERT profiles}

A number of lithological types obtained from the particle size analyses of samples permitted to establish a relationship with the electrical resistivity values obtained from the ERT surveys. The colour scheme representing the dominant lithological types recorded from the borehole logs (Fig. 3) is used to illustrate the interpreted ERT profiles.

Profile RL1-10m (Fig. 4a) cuts across the main geomorphologic features in the site approximately in a south-southeast to northnorthwest direction. The section from 100 to $330 \mathrm{~m}$ presents areas with resistivity values higher than $500 \Omega \mathrm{m}$, these are related to gravelly sand recorded in BhA-S1 (Fig. 3); whereas, the areas showing lower values $(<500 \Omega \mathrm{m})$ are inferred as gravelly muddy sand to gravelly mud recorded in BhD-S1/S2. The section from 330 to $390 \mathrm{~m}$ is dominated by sandy mud, as described in BhE-S1, and is represented by low resistivity values $(<120 \Omega \mathrm{m})$ down to a depth of about $3 \mathrm{~m}$. Resistivity values of $400-800 \Omega \mathrm{m}$ occur from 390 to $405 \mathrm{~m}$, and are related to the presence of an esker ridge composed of cobble gravel (BhF -Fig. 3), approximately $8 \mathrm{~m}$ thick and $20 \mathrm{~m}$ wide. The area along the surface $405-425 \mathrm{~m}$ is dominated by low resistivity values $(<120 \Omega \mathrm{m})$ corresponding to fine sediments. All the materials described above are underlain by low to medium resistivity values (100-500 $\Omega \mathrm{m}$ ). These resistivity values are associated to diamicton composed of gravelly sandy mud and gravelly muddy sand recorded 


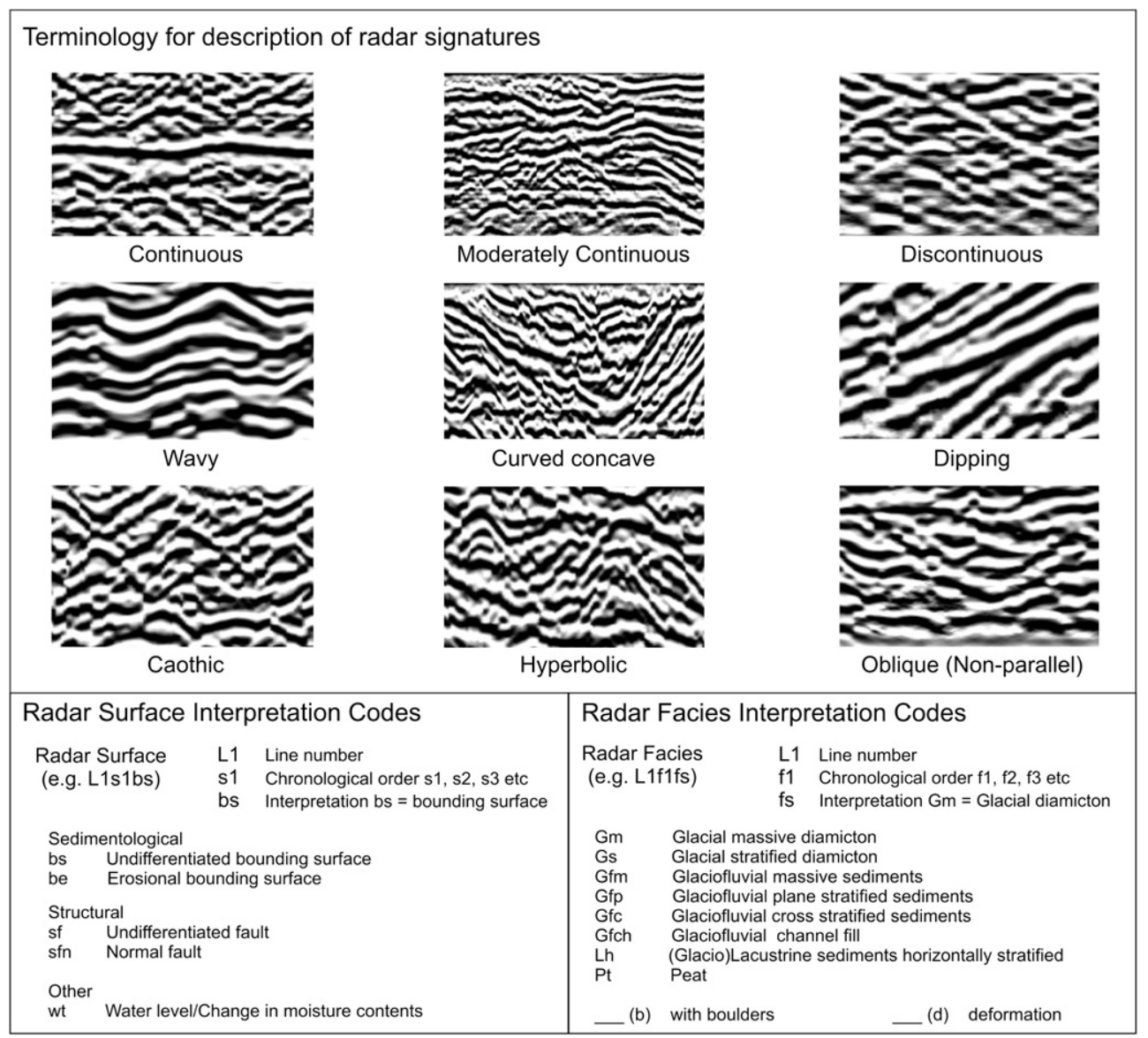

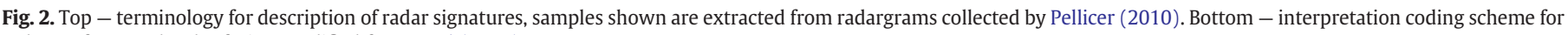
radar surfaces and radar facies, modified from Neal (2004).

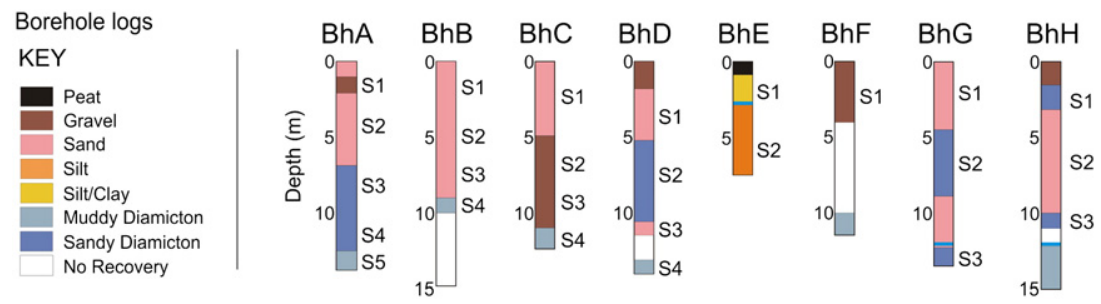

\footnotetext{
Samples classified under the Folk (1954) classification scheme:

BhA: S1-Gravelly sand; S2-Gravelly muddy sand; S3 and S4- Slightly gravelly muddy sand; S5-Slightly gravelly sandy mud

BhB: S1-Slightly gravelly muddy sand; S2 and S3-Gravelly muddy sand: S4-Gravelly mud

BhC: S1-Slightly gravelly muddy sand; S2 and S3-Muddy sandy gravel; S4-Gravelly mud

BhD: S1-Slightly gravelly muddy sand; S2-Gravelly mud; S3-Slightly gravelly muddy sand; S4-Gravelly muddy sand

BhE: S1-Sandy mud; S2-Gravelly mud

BhF: S1-Muddy sandy gravel

BhG: S1-Silty sand; S2 and S3-Gravelly muddy sand

BhH: S1-Gravelly muddy sand; S2-Gravelly sand; S3-Gravelly muddy sand
}

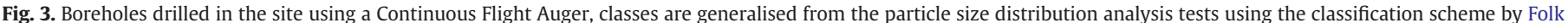
(1954); the colour scheme presented was also used for the interpretation of ERT data.

at the lower levels of $\mathrm{BhA}$ and $\mathrm{BhD}$, this resistivity layer encompasses varying thickness from $5 \mathrm{~m}$ to more than $25 \mathrm{~m}$. The lower part of the profile is dominated by high resistivity values (1000-3000 $\Omega \mathrm{m})$ corresponding to limestone bedrock underlying unconsolidated sediments (Hitzman, 1992). Finally, a lower resistivity zone (600 $\Omega \mathrm{m})$ within the limestone bedrock occurs at 100-125 m, showing a sharp-vertical contact with the surrounding higher resistivity zone. RL1-2m (Fig. 4b) runs inline with L1-10m. It provides a high resolution cross-section of a small portion of the flat-topped area of the fan. The top metre is dominated by values of less than $300 \Omega \mathrm{m}$ related to the presence of gravelly muddy sand recorded in BhA-S2 (Fig. 3).
Two areas showing medium resistivity values ( $>400 \Omega \mathrm{m}$ ) occurring at 8-24 $\mathrm{m}$ and 31-36 $\mathrm{m}$ are associated to gravelly sand recorded in $\mathrm{BhA}-\mathrm{S} 1$. The remaining areas within the profile are dominated by a wide resistivity range, $50-400 \Omega \mathrm{m}$ and are related to slightly gravelly muddy sand recorded in BhA-S3/4.

RL2-10m (Fig. 5a) runs $80 \mathrm{~m}$ west of and subparallel to RL1-10m. Medium to very high resistivity values (500-2000 $\Omega \mathrm{m}$ ) occur along the surface at $0-130 \mathrm{~m}$, reaching maximums of $15 \mathrm{~m}$ depth. The area $130-210 \mathrm{~m}$ is dominated by low values $(<150 \Omega \mathrm{m})$ reaching maximum depth of $8 \mathrm{~m}$ and probably related to the presence of sandy mud, as recorded in BhE-S1 (Fig. 3). The area to the north, 

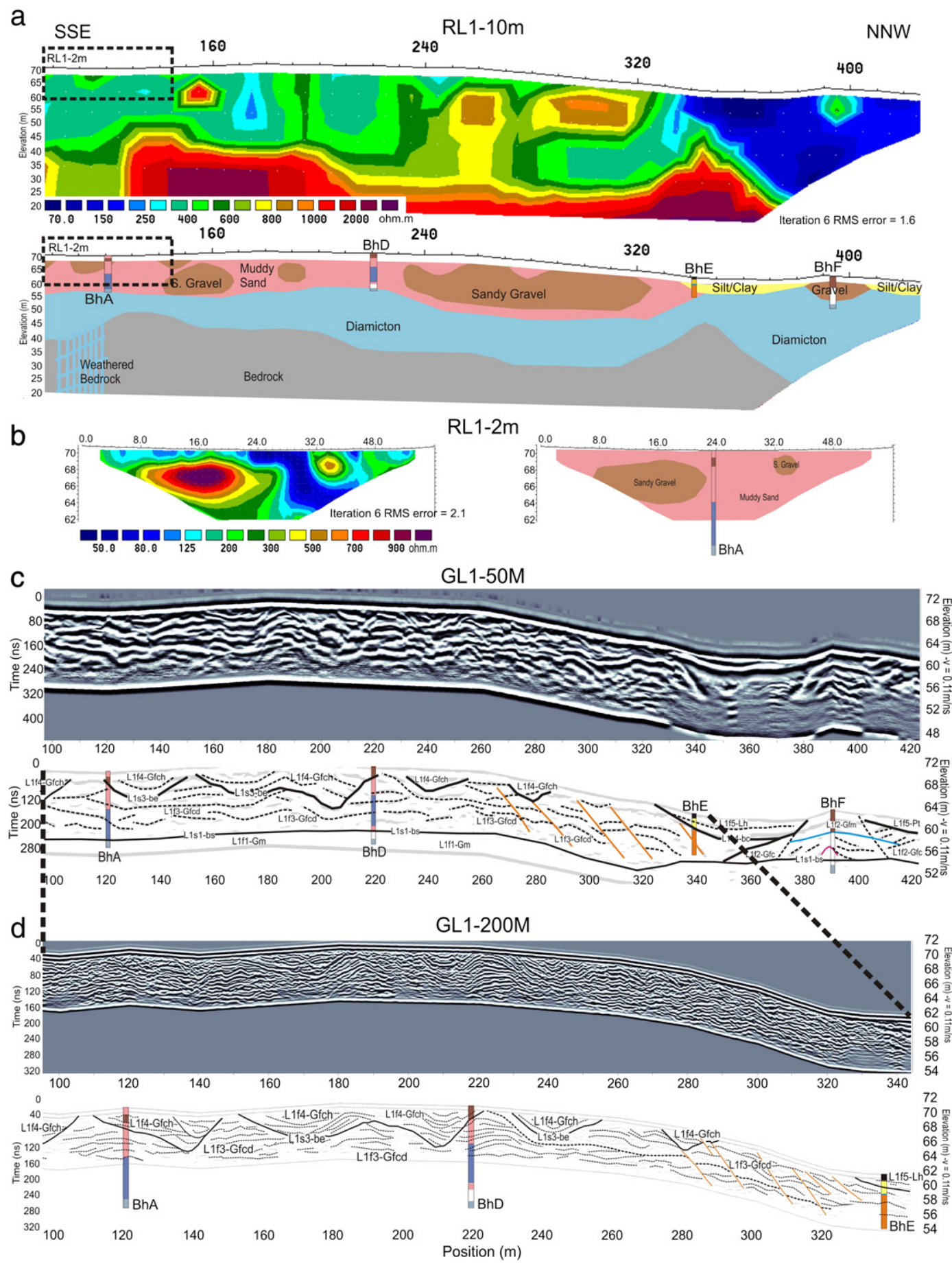

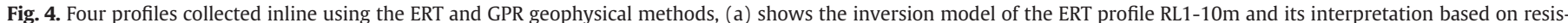

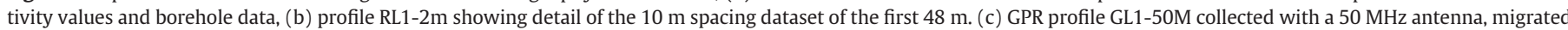

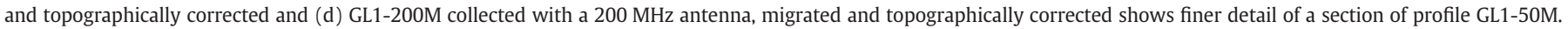

dominated by medium resistivity (c. $500 \Omega \mathrm{m}$ ), is related to boulder gravel shaping the esker ridge. These sediments are underlain by low to medium resistivity values (150-300 $\Omega \mathrm{m}$ ) interpreted as diamicton in $\mathrm{BhH}$, which are underlain by a high resistivity (>1200 $\Omega \mathrm{m}$ ) related to the presence of bedrock.

RL3-10m (Fig. 5b) runs along the silt/clay dominated lowland located at the southern margin of the esker ridge. High resistivity values dominating the lower areas $(>1700 \Omega \mathrm{m})$ at $50-20 \mathrm{~m}$ OD are associated to limestone bedrock also depicted in RL1-10m. A layer pinching out westwards at $140-210 \mathrm{~m}$ showing medium to high values (600-1700 $\Omega \mathrm{m}$ ) overlies the bedrock. These resistivity layers are overlain by low resistivity values $(<400 \Omega \mathrm{m})$, which probably comprise sandy mud and gravelly mud as recorded in BhE (Fig. 3 ).

RL4-5m (Fig. 5c) is composed of three concatenated profiles at $5 \mathrm{~m}$ electrode spacing which cut obliquely across the main geomorphologic feature in the site (flat-topped fan) in a southwest to northeast direction. A low resistivity region $(<250 \Omega \mathrm{m})$, occurring on the surface from 0 to $40 \mathrm{~m}$ and developing towards deeper parts is mapped as a continuous gently undulating layer occurring under $55 \mathrm{~m}$ OD and is associated to diamicton composed of gravelly mud and gravelly muddy sand recorded at the lower parts of BhC/D/G. This layer is underlain in places by higher resistivity values 


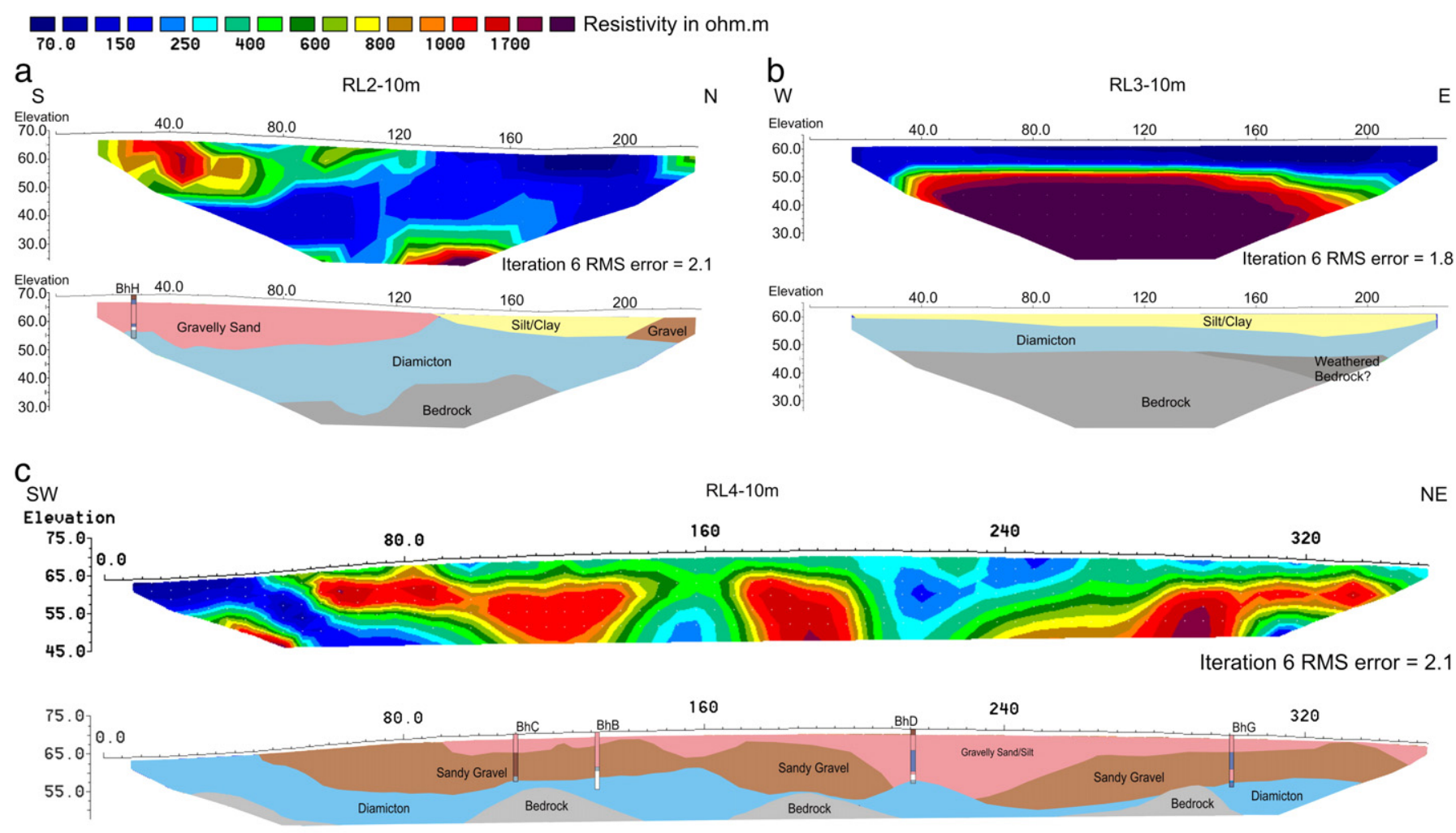

Fig. 5. ERT profiles (a) RL2-10m, (b) RL3-10m and (c) RL4-5m showing the inversion model and their interpretation based on resistivity values and borehole data.

$(>1700 \Omega \mathrm{m})$ representing undulating limestone bedrock. The diamicton is overlain by high resistivities ( $>800 \Omega \mathrm{m}$ ) from 40 to $210 \mathrm{~m}$ and 240 to $360 \mathrm{~m}$ associated to muddy sandy gravel and gravelly muddy sand recorded in $\mathrm{BhB} / \mathrm{C} / \mathrm{G}$. This sand and gravel body is overlain by a layer presenting low to medium resistivity (150-400 $\Omega \mathrm{m}$ ) from 90 to $360 \mathrm{~m}$ with large variations in thickness related to muddy sand recorded on $\mathrm{S} 1$ for boreholes $\mathrm{BhB} / \mathrm{C} / \mathrm{D} / \mathrm{G}$.

\subsubsection{GPR profiles}

The raw and filtered GPR radargrams were visually analysed for data interpretation; visual analysis of non-filtered datasets permits the identification of features removed by the filtering process (e.g. migration of the data removes hyperbolae from radargrams, which allow depicting presence of boulders or channel-like features, as well as, estimating wave velocities). However, only the filtered radargrams are shown in the figures presented. The location of GPR profiles is illustrated in Fig. 1. Common midpoint and hyperbolae fitting were used for velocity calibration of the radargrams. A common midpoint profile was collected in the fan area between boreholes $\mathrm{BhB}$ and BhC (Fig. 1), the velocity obtained ranged between $0.10 \mathrm{~m} / \mathrm{ns}$ and $0.12 \mathrm{~m} / \mathrm{ns}$. Hyperbolae reflections depicted in profile GL1-200M were used for velocity calibration of the flat poorly drained low ground area (Fig. 1) at $0.8 \mathrm{~m} / \mathrm{ns}$. Velocity calibration along the esker ridge was also performed by hyperbolae fitting, a velocity of 0.10 $0.11 \mathrm{~m} / \mathrm{ns}$ was obtained. Based on these data a velocity of $0.11 \mathrm{~m} / \mathrm{ns}$ was selected for data processing and topographic correction. Depth estimates in the sections of the profiles collected in the flat low ground area with subsurface velocities of $0.8 \mathrm{~m} / \mathrm{ns}$ encompass large errors. However, the data processing software available for this study allowed only a single velocity for velocity correction of the data. The distortion of the radargrams cutting across this area was taken into account during data interpretation.

GL1-50M (Fig. 4b) reaches a maximum depth of investigation of $14 \mathrm{~m}$. Five radar facies are identified along the profile. The area along the lower parts of the profile showing poor reflectivity (L1f1-Gm) corresponds to diamicton composed of gravelly sandy mud and gravelly muddy sand, as shown in BhA-S5 and BhD-S4. This is overlain from 380 to $410 \mathrm{~m}$ by chaotic reflectors agreeing with the muddy sandy gravel recorded in BhE-S1 and forming the core of an esker ridge with moderate topographic expression (L1f2-Gfm). A number of dipping reflectors spread from both flanks of the ridge (L1f2-GfC) are probably associated with this ridge. A third radar facies (L1f3-Gcd) occurs from 100 to $330 \mathrm{~m}$. It is composed of discontinuous to moderately continuous wavy reflectors indicative of cross-stratified sediments. A set of moderately continuous reflectors dipping $30^{\circ} \mathrm{NNW}$ are depicted at the edge of the fan at $280-340 \mathrm{~m}$ (Fig. 4c,d). These are overlain by several curved concave reflectors (L1f4-Gfch) associated to gravelly sand recorded in BhA-S1, these facies range from 15 to $30 \mathrm{~m}$ in width and 4 to $7 \mathrm{~m}$ in depth and show an erosive contact (L1s3-be) with the underlying sediments. Furthermore, a continuous reflector subparallel to the surface occurs at 330-380 m (L1f5-Lh). The EM are significantly attenuated in this area, indicating the presence of conductive fine sediments, as recorded in BhE-S1 (Fig. 3). The radargram is fairly distorted in this section, as the velocity of these sediments is $0.8 \mathrm{~m} / \mathrm{ns}$ instead of $0.11 \mathrm{~m} / \mathrm{ns}$, thus the contact between $\mathrm{f} 3$ and f5 illustrated at $3 \mathrm{~m}$ depth (Fig. $4 \mathrm{~b}$ ) in the radargram is in fact at $2 \mathrm{~m}$ depth. Finally, a moderately continuous reflector running subparallel to the subsurface illustrated in blue (Fig. 4c,d) corresponds to the water level recorded in BhF (Fig. 3). GL1-200M (Fig. 4c) provides a higher resolution radargram of GL1-50M, four radar facies are recognised. A number of reflectors gently dipping NNW (L1f2-Gfm) are detected within the esker (Fig. 6), which correspond to the gently dipping beds of boulder/cobble gravel recorded in exposure EX-A. Several moderately continuous reflectors dipping $30^{\circ} \mathrm{NNW}$ are detected at the edge of the fan (240$290 \mathrm{~m}$ ).Moreover, the erosive contact (L1s3-be) between $\mathrm{f} 3$ and $\mathrm{f} 4 \mathrm{is}$ clearly delineated and depositional structures within $\mathrm{f} 4$ are sensed (e.g. continuous reflectors dipping SSE and concave up reflectors interpreted as channel-like features). Four boreholes were drilled along 
these profiles. The main lithological types recorded in the boreholes (Fig. 3) agree with the depicted radar facies: L1f1-Gm relates to BhA-S5 and BhD-S4; L1f2-Gfm is defined by BhF-S1; L1f3-Gfcd corresponds to BhA/D-S2; L1f4-Gfch is in accordance with BhA-S1; L1f5-Lh concurs with BhE-S1.

A cross and a longitudinal section of the esker ridge are presented in Fig. 6 as a fence diagram of the interpreted profiles GL1-200M and GL2-200M. A continuous horizontal reflector running along the two profiles at $59 \mathrm{~m}$ OD is inferred as the water-table, as recorded in BhF. A set of moderately continuous and discontinuous oblique, non-parallel reflectors are depicted under $59 \mathrm{~m}$ OD (L2f2-Gfc). These are overlain at $0-40 \mathrm{~m}$ along GL2-200M by discontinuous chaotic and hyperbolic reflectors (L2f2-Gfm), associated to the presence of cobbles along the esker ridge, as recorded in EX-A. The top $4 \mathrm{~m}$ of GL2-200M from 40 to $80 \mathrm{~m}$ are dominated by moderately continuous reflectors dipping $10^{\circ} \mathrm{WSW}$ (L2f2-Gfs). Such reflectors are also recognised along line GL12-200M and in exposure EX-A dipping north. The estimated dip direction of the bedding planes is approximately NW.

GL3-100M profile (Fig. 7a) runs southwest to northeast along the flat-topped elongated fan. Two radar facies are identified. L3f3-Gfc consists of moderately continuous to discontinuous sinuous subparallel reflectors. Continuous curved concave up, sinuous in places, reflectors (L3f4-Gfch) overlie the former with an erosive contact (L3-s3-be). Radar facies $\mathrm{f} 4$ are described in boreholes $\mathrm{BhD} / \mathrm{G}$ as muddy sand and are related to the channel-like features identified in GL1-200M. The profile cuts these radar facies at oblique angles in places, the area 0 $180 \mathrm{~m}$ and $200-240 \mathrm{~m}$ at $0-6 \mathrm{~m}$ depth shows a long-oblique section of the mentioned channel-like features (L1f4-Gfch).

GL4-100M (Fig. 7b) presents two radar facies, L4f3-Gfc is expressed in the radargram by moderately continuous to discontinuous oblique/ subparallel reflectors with some occurrences of reflectors dipping east (20-50 $\mathrm{m}$ at $4 \mathrm{~m}$ depth and $210-230 \mathrm{~m}$ at $5 \mathrm{~m}$ depth). Continuous curved concave up reflectors (L4-f4-Gfch) overlie the former with an erosive contact (L4-s3-be). A feature at $180 \mathrm{~m}$ and $67 \mathrm{~m}$ OD, is shown in the non-processed profile as a distinctive bow-tie reflector, characteristic of V-shaped channel features (Neal, 2004). Furthermore, three moderately continuous reflectors dipping $30^{\circ} \mathrm{E}$ are recorded at 220 $250 \mathrm{~m}$ distorting radar facies $\mathrm{f} 3$ and $\mathrm{f} 4$.

\section{Discussion}

Geological surveying, consisting of geomorphological mapping and lithostratigraphic analysis of exposures, allowed the broad distribution of surficial sediments to be assessed but lack of exposure is a difficulty. The geotechnical data permitted the lithological characterisation of the subsurface at eight given points and assisted in the location of the geophysical surveys which provided data over large areas. Geological mapping and the geotechnical investigations supported

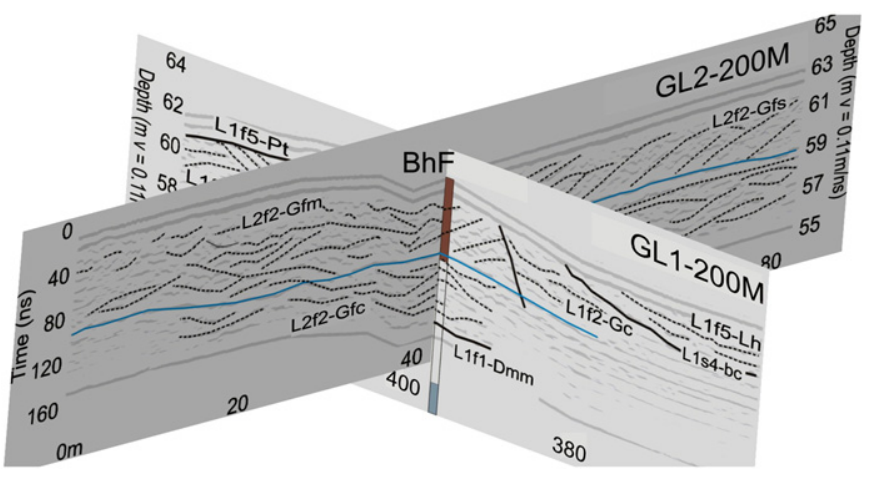

Fig. 6. Fence diagram showing the interpreted radargrams of a cross-section (GL1$200 \mathrm{M}$ ) and a long-section (GL2-200M) of the esker ridge and the log for BhE. the interpretation of the geophysical data and provided 'ground truth' in assessing the use of ERT and GPR for recognition and characterisation of surficial sediments.

Five lithological classes were differentiated by means of ERT surveys supported by field mapping and borehole data, which in chronological order of deposition are: (i) limestone bedrock, (ii) diamicton, (iii) esker gravel and boulders, (iv) gravelly sand/silt and sandy gravel and (v) lacustrine sandy mud. These classes are characterised from the results of resistivity modelling, however, borehole data, geomorphological evidence and GPR data assisted in the delineation of the lithological boundaries. Areas located at the bottom region of the $10 \mathrm{~m}$ spacing profiles characterised by high to very high resistivity values $(>900 \Omega \mathrm{m})$ are interpreted as limestone bedrock. Depth to bedrock ranges from 12 to $38 \mathrm{~m}$, a number of possible weathered bedrock areas showing resistivities lower than $900 \Omega \mathrm{m}$ are also depicted in RL1 (Fig. 4a) and RL3 (Fig. 5b). A low to medium resistivity layer $(80-400 \Omega \mathrm{m})$ overlying the bedrock is depicted as a continuous body with varying thickness in all profiles. This varies from less than $1 \mathrm{~m}$ in areas underlying the fan up to $25 \mathrm{~m}$ in the lower ground area to the north and is interpreted as diamicton, probably of glacial origin. Two resistivity layers defined by medium to high resistivity values (300-1500 $\Omega \mathrm{m}$ ) are described as gravelly sand/silt (pink colour in RL1, RL2 and RL4) and as sandy gravel (brown colour in RL1 and RL4) overlie the diamicton in the area morphologically defined as a fan. These layers correspond to glaciofluvial sediments reaching a thickness of over $10 \mathrm{~m}$ in the middle area of the fan and pinching out towards its southern and northern margins. An isolated patch $20 \mathrm{~m}$ wide and $8-10 \mathrm{~m}$ thick in its central parts is identified in RL1 and partially in RL2 overlying the diamicton encompassing 400$700 \Omega \mathrm{m}$ resistivity values. This is interpreted as an esker ridge, which is generally composed of boulders and muddy sandy gravel (See BhF in Fig. 3). Finally, a lithological category dominated by low resistivity $(60-120 \Omega \mathrm{m})$ is recognised in RL1, RL2 and RL3. It is interpreted as glaciolacustrine sand, silt and clay occurring along the surface at the northern and southern margins of the esker ridge overlying the diamicton. It reaches a maximum thickness of $8 \mathrm{~m}$ in the middle area of the body located south of the esker and gradually pinches out towards its northern and southern margins. On the other hand, ERT spatial resolution depends on three factors: the electrode spacing, the resistivity contrast between the different lithologies and the relative position between these features (Kilner et al., 2005). Features, interpreted as gravel channels with the $10 \mathrm{~m}$ electrode spacing, are shown as gravel lenses with the $2 \mathrm{~m}$ spacing. High resolution dataset shows variations of the resistivity values within very short distances indicating lithological changes overlooked by the lower resolution dataset. On the other hand, depth of penetration is largely increased with the $10 \mathrm{~m}$ spacing dataset, which permitted inferring the presence of limestone bedrock underlying the unconsolidated sediments and depicting a sharp and vertical structure (Fig. 4a, 100-120 m) interpreted as karstified limestone bedrock. The combination of different electrode spacing aids in the refinement of the interpretation of the inversion models. Moreover, a disagreement was recorded between the rock head level portrayed by profile RL3-10m ( $50 \mathrm{~m}$ OD) and the rock head level encountered by profiles RL1/RL2-10m cutting across it, which consistently show rock head level at less than $45 \mathrm{~m}$ OD. This illustrates the limitations of the system to precisely depict the contact between materials when using a single profile and emphasises the need to record profiles at different orientations and combining ERT data with other direct (borehole drilling) or indirect (geophysics) methods to refine the interpretation of resistivity data.

The use of several GPR antenna frequencies for the same survey area is recommended by Jol and Bristow (2003) in order to resolve sedimentological structures at different scales. The results for GL1-50/200M show that the $50 \mathrm{MHz}$ antenna frequency allowed coarse characterisation of the internal architecture up to $14 \mathrm{~m}$ depth, whereas, the 
a

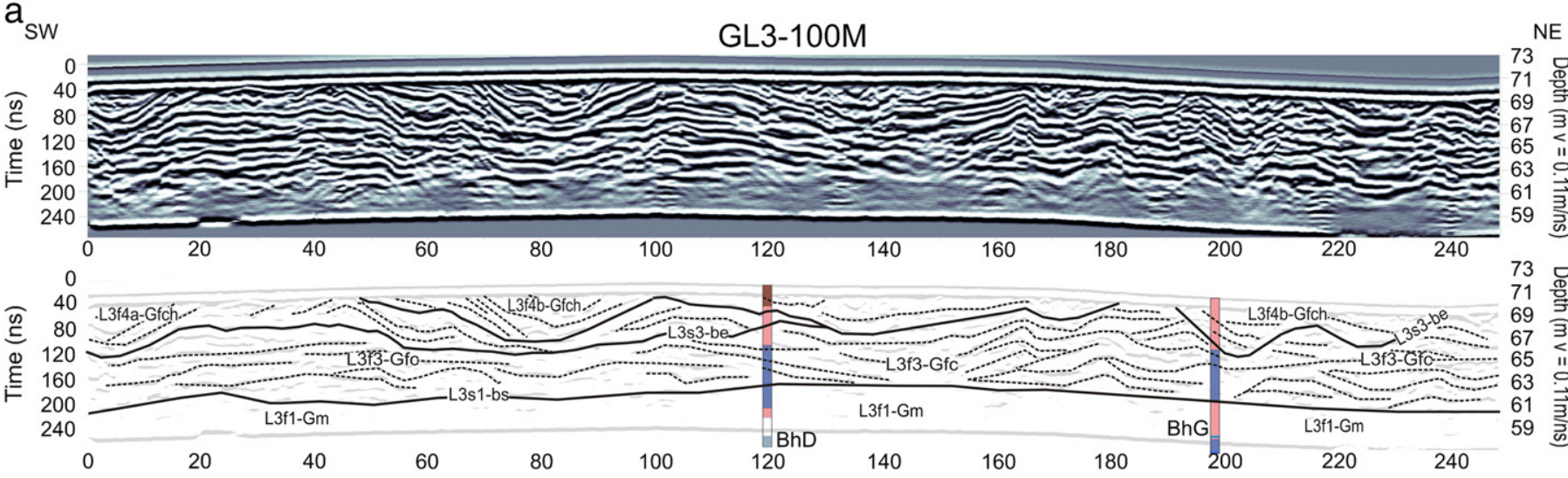

b

w GL4-100M

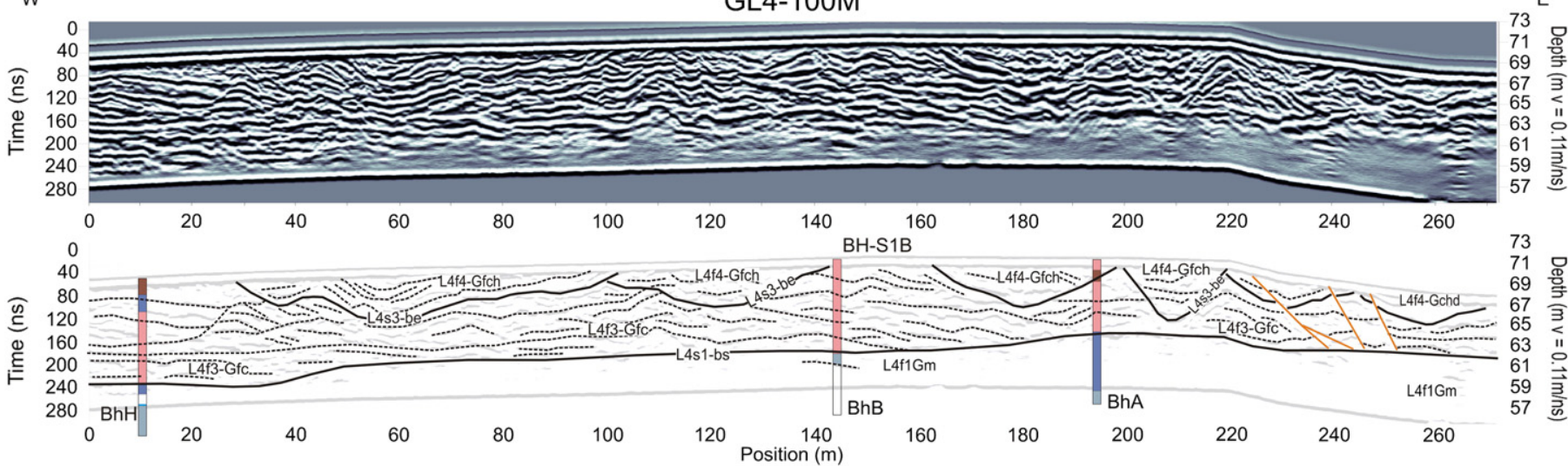

Fig. 7. GPR profiles (a) GL3-100M and (b) GL4-100M. Top - processed radargrams with an AGC gain and topographic correction. Bottom - interpretation of each radargram.

$200 \mathrm{MHz}$ antenna permitted the detection of the water table, normal fault planes and the contact between facies f3 and f4. The $100 \mathrm{MHz}$ antenna frequency used for GL3 and GL4 seems to offer the best trade off between penetration and resolution.

GPR data allowed the characterisation of the subsurface internal architecture. Five radar facies were identified, which in chronological order from older to younger are: (i) f1-Gm - glacial massive diamicton; (ii) f2-Gfm/Gfc - glaciofluvial massive/cross stratified sediments associated with the esker ridge; (iii) f3-Gcd(d) - glaciofluvial crossstratified sediments, deformed in places associated with the fan; (iv) f4-Gch(d) - glaciofluvial channel fill sediments, deformed in places associated with the fan and; (v) f5-Lh - glaciolacustrine horizontally stratified fine sediments. Radar facies $\mathrm{f} 1$, characterised by its poor reflectivity, is depicted at the lower parts of radargram GL1-50M (Fig. 4c) overlain by f2 and f3. Radar facies $\mathrm{f} 2$ is depicted in GL1 and GL2 (Fig. 6) overlying f1 with an undifferentiated bounding surface; it is described as discontinuous oblique chaotic reflectors, hyperbolae and as moderately continuous dipping reflectors in places. It corresponds to the deposits forming the core of the esker ridge which were recorded in exposure EX-A as crudely bedded cobble/boulder gravel. Radar facies f3, depicted within the fan area (Figs. 4c,d and 7 ), is described by moderately continuous to discontinuous oblique/ subparallel reflectors and sinuous/subhorizontal subparallel reflectors and it is composed of silty sand and gravelly muddy sand. Radar facies f4, recognised within the fan area in radargrams GL1, GL3 and GL4 (Figs. 4c,d and 7). These are characterised by continuous curved concave reflectors sinuous in places generally occurring along the surface, overlying $\mathrm{f} 3$ with an erosional bounding surface and composed of gravelly sand, silty sand and slightly gravelly muddy sand. Radar facies f5, identified in GL1, covers the lower ground area between the esker ridge and the fan. It is characterised for reflectors subparallel to the surface composed of slightly gravelly sandy mud and is interpreted as glaciolacustrine silts and clays overlain by a thin coating of peat. Furthermore, a number of sets of discontinuous to moderately continuous dipping reflectors, interpreted as normal faults, are depicted in GL1 and GL4 (Figs. 4c,d and 7). These faults are probably associated with collapse structures derived from loss of support of the edges of an ice contact lake acting as a temporary small scale sedimentary basin.

The radar facies obtained from GPR data show correspondence with the lithological classes defined from the ERT and borehole data (Table 1), the integration of the two geophysical datasets together with the geotechnical investigations allows a comprehensive sedimentological and lithological characterisation of the subsurface. Resistivity values for the lithological types defined in Table 1 agree with previous research (Guerin et al., 2004; Palacky, 1987; Reynolds, 1997) and radar facies identified in the study area correspond with facies previously recognised by other authors (Bakker and van der Meer, 2003; Moorman et al., 2003; Neal, 2004). Each technique has its own advantages and drawbacks. GPR data provide, in ideal conditions (e.g. low conductivity sediments), a high resolution picture of the internal architecture of the subsurface, however, the depth of penetration is very poor in high conductivity sediments (e.g. silts/clays -Fig. 4). The maximum depth of penetration attained in the site is $14 \mathrm{~m}$. On the other hand, the ERT method allowed the production of profiles of up to $40 \mathrm{~m}$ depth and clearly detects vertical and horizontal features. However, the level of detail attained at this depth is much lower and internal architecture of the subsurface cannot be recognised using this technique alone.

Geophysical characterisation aided to reconstruct the glacial history of the study area. An esker ridge with poor topographic expression and dominated by cobble/boulder gravel cuts across the north 
Table 1

ERT lithological classes and GPR radar facies identified in the study area.

\begin{tabular}{|c|c|c|c|}
\hline Relative chronology & Resistivity $(\Omega \mathrm{m})$ & ERT lithological classes & GPR radar facies \\
\hline 6 (younger) & $60-120$ & Silt and clay & f5-Lh - lacustrine sediments \\
\hline 5 & $300-800$ & Gravelly sand/silt & f4-Gch(d) - glaciofluvial channel fill (fan) \\
\hline 4 & $400-1500$ & Sandy gravel & f3-Gcd(d) - glaciofluvial cross stratified (fan) \\
\hline 3 & $500-1000$ & Esker gravel and boulders & $\mathrm{f} 2-\mathrm{Gfm} / \mathrm{Gfc}-$ glaciofluvial massive (esker ridge) \\
\hline 2 & $80-400$ & Diamicton & f1-Gm - glacial massive \\
\hline 1 (older) & $>900$ & Bedrock & Not detected \\
\hline
\end{tabular}

margin of site from west to east. An elongated fan running parallel to the lower lying esker occurs south of it. These features are separated by a stretch of glaciolacustrine sediments, but merge east and west of the site into a single entity. The fan is wedge shaped, widening to the east. Borehole data show that the fan is composed of sandy gravel, gravelly sand to muddy sand generally fining eastwards, GPR data depicts a number of cut-and-fill channel-like features running west-east and generally filled with sand and silty sand. The geological settings encountered in the site are complex. Diamicton overlying the bedrock was deposited under subglacial conditions; these deposits are overlain by two main features, the esker ridge and the fan. The existence of Glacial Lake Riada with an approximate water level at $92 \mathrm{~m}$ OD (Delaney, 2002, 2008) requires these features to form either under subglacial or subaqueous conditions. The formation of subaqueous outwash fans associated with eskers can develop either, (i) subglacially within side cavities adjacent to the main tunnel formed in areas with high hydrostatic pressure (Gorrell and Shaw, 1991), (ii) near the ice margin, as ice-walled channel deposits, defined by the ratio of their length to their width and defined as long bead eskers by Warren and Ashley (1994), or (iii) at the ice margin snout as short bead eskers or ice marginal subaqueous fans (Warren and Ashley, 1994). Subglacial deposits are generally draped by a coating of diamicton (Fisher and Taylor, 2002). The esker ridge is dominated by poorly sorted cobble, boulder gravel (EX-A) overlain by diamicton. This suggests that cobble/boulder gravel was deposited in a high energy depositional system under subglacial conditions as tunnel-fill esker deposits (Warren and Ashley, 1994); subsequent melting of the overlying ice deposited the debris included in it as a coating of diamicton. Conversely, sedimentation of the fan occurred as a confined ice marginal subaqueous fan or long bead esker. Dipping reflectors depicted after a concave change in slope in GL1-50/200M at the northern margin of the fan and in GL4-100M at its southeast margin are interpreted as normal faults. These faults and the geomorphological expression of the body as a long bead esker running west to east, suggest that deposition occurred in a channel-like system confined to its north and south margins by ice walls and opened to its outlet to the east. The sediment collapsed after ice melting and developed the normal faults dipping towards the former ice walls located at the north and south margins of the feature, ice-contact lithofacies typically show collapse and deformational structures created by mass movement when the supporting ice walls slowly melt (Ashley and Warren, 1997). This subaqueous fan is connected to the tunnel fill esker ridge (Warren and Ashley, 1994), west from the study area. This suggests that the feature is associated with the subglacial tunnel fill deposits (Ashley and Warren, 1995). The fan, located at a higher level (72 m OD), accommodated finer, better sorted sediments filling a confined low energy depositional system composed of gravelly sand at its west margin fining to muddy sand eastwards. The numerous channel-like features identified on GPR running west to east are probably formed by resedimentation of material from further up the fan deposited via underflows and suspension on a subaqueous fan (Delaney, 2002). The top of the subaqueous fan has an altitude of $72 \mathrm{~m} \mathrm{OD}$, which agrees with the presence of Glacial Lake Riada flooding the Irish Midlands with a water table at $92 \mathrm{~m}$ OD (Delaney, 2002). Glaciolacustrine sediments located between the fan and the esker ridge were subsequently deposited; these are composed of silt/clay with occasional pebbles, probably dropstones deposited at a later stage as distal facies of ice marginal deposits in a glacial lake environment (van der Meer and Warren, 1997). A thin coating of peat developed subsequently on top of these sediments within the site and as thicker deposits along the northern margin of the esker. Peat deposits suggest the presence of a shallow lake covering the most depressed areas of the site during postglacial times. Peat deposits in the site have been cut away, they encompass thickness of less than $30 \mathrm{~cm}$. Peat deposits have been extensively cut-away in the Irish Midlands during the last century (Gibson, 2007).

\section{Conclusions}

Geomorphological mapping, exposure lithostratigraphic analysis, borehole logging and particle size distribution analysis data combined with ERT and GPR data allowed the lithological and sedimentological characterisation of the subsurface. ERT data collected with three different electrode spacings supported the lithological characterisation of unconsolidated sediments and allowed estimating the depth to bedrock. GPR proved invaluable at depicting the internal architecture of low-loss materials such as esker gravel and glaciolacustrine sediments. Using a range of antenna frequencies resulted in the detection of the subsurface internal architecture at different scales. The radar facies approach used for data interpretation allowed patterns encountered in the radargrams to be related to sedimentological properties of the subsurface. ERT and GPR data complemented each other and together provided a broad understanding of the subsurface geology. The integration of these techniques with field and laboratory data permitted the geological characterisation of the site and the reconstruction of the depositional environment. The data presented suggest deposition of the recorded facies by an ice sheet retreating westwards. Firstly, diamicton was deposited subglacially over limestone bedrock. A continuous tunnel fill esker ridge (Geashill Esker) was then deposited overlying the diamicton under subglacial conditions infilling a subglacial meltwater channel running east. A subaqueous fan, indicating a lake water table of over $72 \mathrm{~m} \mathrm{OD}$, was deposited parallel to the continuous tunnel fill as a long beaded esker ridge composed of silt, sand and gravel overlying the subglacial diamicton. Glaciolacustrine silts and clays were subsequently deposited on the lower ground between the esker ridge and the fan at a later stage of deglaciation. Furthermore, peat developed during post-glacial times in a lake covering parts of the study area and extending north from the esker ridge, peat deposits in the study area were subsequently cut-away by anthropogenic activity.

\section{Acknowledgments}

The geophysical equipment used for this work was provided by the National University of Ireland, Maynooth Environmental Geophysics Unit. The Geological Survey of Ireland (GSI) funded the fieldwork and provided all the equipment for exposure recording, borehole drilling and particle size analysis. The authors would like to thank Caloca, S., Mozo, B., Sheehy, M. and Fernandez, N. for help in data collection and Cox, M. for facilitating access to the site. We also thank Dr. Xavier 
Comas for the constructive review comments, which enhanced the quality of an earlier version of the manuscript.

\section{References}

Ashley, G.M., Warren, W.P., 1995. Irish eskers/origins of ice-contact stratified deposits. INQUA Commission on Formation and Properties of Glacial Deposits. Symposium and Field Excursion 21-28 May. 59 pp.

Ashley, G.M., Warren, W.P., 1997. The ice-contact environment. Quaternary Science Reviews 16, 629-634.

Baines, D., Smith, D.G., Froese, D.G., Bauman, P., Nimeck, G., 2002. Electrical resistivity ground imaging (ERGI): a new tool for mapping the lithology and geometry of channel-belts and valley-fills. Sedimentology 49, 441-449.

Bakker, M.A.J., van der Meer, J.J.M., 2003. Structure of a Pleistocene push moraine revealed by GPR: the eastern Veluwe Ridge, The Netherlands. Ground Penetrating Radar in Sediments: In: Bristow, C.S., Jol, H.M. (Eds.), Geol. Soc. London Spec. Publ., 211, pp. 143-151.

Ballantyne, C.K., McCarroll, D., Stone, J.O., 2006. Vertical dimensions and age of the Wicklow Mountains ice dome, Eastern Ireland, and implications for the extent of the last Irish ice sheet. Quaternary Science Reviews 25 (17-18), 2048-2058.

Ballantyne, C.K., McCarroll, D., Stone, J.O., 2007. The Donegal ice dome, northwest Ireland: dimensions and chronology. Journal of Quaternary Science 22, 773-783.

Ballantyne, C.K., Stone, J.O., McCarroll, D., 2008. Dimensions and chronology of the last ice sheet in Western Ireland. Quaternary Science Reviews 27 (3-4), 185-200.

Benn, D.I., Evans, D.J.A., 1998. Glaciers and Glaciation. Arnold, London.

BS EN ISO 22476-2:2005, 2006. Geotechnical Investigation and Testing. 0580476367 Claerbout, J.F., Muir, F., 1973. Robust modelling with erratic data. Geophysics 38, 826-844

Comas, X., Slater, L., Reeve, A., 2004. Geophysical evidence for peat basin morphology and stratigraphic controls on vegetation observed in a northern peatland. Journal of Hydrology 295, 173-184

Comas, X., Slater, L., Reeve, A., 2011. Pool patterning in a northern peatland: geophysical evidence for the role of postglacial landforms. Journal of Hydrology 399 (3-4) 173-184.

Delaney, C.A., 2002. Sedimentology of a glaciofluvial landsystem, Lough Ree area, Central Ireland: implications for ice margin characteristics during Devensian deglaciation. Sedimentary Geology 149, 111-126.

Delaney, C.A. 2008. Seasonal controls on deposition of Late Devensian glaciolacustrine sediments, Central Ireland. Glacial Sedimentary Processes and Products. : In: Hambrey, M., Christoffersen, P., Glasser, N., Jansen, P., Hubbard, B., Siegert, M. (Eds.), Special Publication. International Association of Sedimentologists, Oxford, Blackwells, pp. 146-163.

Doetsch, J., Linde, N., Pessognelli, M., Green, A.G., Günther, T., 2011. Constraining 3-D electrical resistance tomography with GPR reflection data for improved aquifer characterization. Journal of Applied Geophysics. doi:10.1016/j.jappgeo.2011.04.008.

Farrington, A., Synge, F.M., 1970. Three local studies of the Irish Pleistocene, the eskers of the Tullamore District. In: Stephens, N., Glassock, R. (Eds.), Irish Geographical Studies, Queens University of Belfast, pp. 49-52.

Feehan, J., Dunne, L., 2003. Ireland's Mushroom Stones. Relics of a Vanished Lakeland. Environmental Resource Management, University College Dublin.

Fisher, T.G., Taylor, L.D., 2002. Sedimentary and stratigraphic evidence for subglacial flooding, south-central Michigan, USA. Quaternary International 90, 87-115.

Folk, R.L., 1954. The distinction between grain size and mineral composition in sedimentary-rock nomenclature. Journal of Geology 62, 344-359.

Gibson, P.J., 2007. Heritage Landscapes of the Irish Midlands and Selected Itineraries. Geography Publications, Dublin.

Gorrell, G., Shaw, J., 1991. Deposition in an esker, bead and fan complex, Lanark, Ontario, Canada. Sedimentary Geology 72, 285-314.

deGroot-Hedlin, C., Constable, S., 1990. Occam's inversion to generate smooth, twodimensional model from magnetotelluric data. Geophysics 55, 1613-1624.

Greenwood, S.L., Clark, C.D., 2009a. Reconstructing the last Irish Ice Sheet 1: changing flow geometries and ice flow dynamics deciphered from the glacial landform record. Quaternary Science Reviews 28, 3085-3100.

Greenwood, S.L., Clark, C.D., 2009b. Reconstructing the last Irish Ice Sheet 2: a geomorphologically-driven model of ice sheet growth, retreat and dynamics. Quaternary Science Reviews 28, 3101-3123.

Guerin, R., Munoz, M.L., Christophe, A., Laperrelle, C., Hidra, M., Drouart, E., Grellier, S. 2004. Leachate recirculation: moisture content assessment by means of a geophysical technique. Waste Management 24, 785-794.
Hirsch, M., Bentley, L.R., Dietrich, P., 2008. A comparison of electrical resistivity, ground penetrating radar and seismic refraction results at a river terrace site. Journal of Environmental and Engineering Geophysics 13 (4), 325-333.

Hitzman, M.W., 1992. Bedrock geological map of the Carboniferous of Central Ireland (1:100,000 Scale, O.S.Sheets 12,13,15, 16, 18 and 19. Geological Survey of Ireland.

Jol, H.M., Smith, D.G., 1991. Ground penetrating radar of northern lacustrine deltas. Canadian Journal of Earth Sciences 28, 1939-1947.

Jol, H.M. Bristow, CJ. 2003. GPR in sediments: advice on data collection, basic processing and interpretation, a good practice guide. In: Bristow, C.J., Jol, H.M. (Eds.), Ground Penetrating Radar in Sediments. The Geological Society, London, pp. 9-29.

Kilner, M., Westa, L.J., Murray, T., 2005. Characterisation of glacial sediments using geophysical methods for groundwater source protection. Journal of Applied Geophysics 57 (4), 293-305.

Kittredge, N., Comas, X., Baird, A., Slater, L., Strack, M., Thompson, D., Jol, H.M., Binley, A., 2008. Ecohydrologically-important subsurface structures in peatlands are revealed by Ground-Penetrating Radar and resistivity measurements. Journal of Geophysical Research, Biogeosciences 113, G04030. doi:10.1029/2008JG000787.

Loke, M.H., 2001. Electrical imaging surveys for environmental and engineering studies. A Practical Guide to 2-D and 3-D Surveys: RES2DINV Manual, IRIS Instruments. www.iris-instruments.com

Loke, M.H., Barker, R.D., 1996. Rapid least squares inversion of apparent resistivity pseudosections by a quasi-Newton method. Geophysical Prospecting 44, 131-152.

McClymont, A.F., Roy, J.W., Hayashi, M., Bentley, L.R., Maurer, H., Langston, G., 2011. Investigating groundwater flow paths within proglacial moraine using multiple geophysical methods. Journal of Hydrology 399, 57-69.

van der Meer, J.J.M., Warren, W.P., 1997. Sedimentology of late glacial clays in lacustrine basins, Central Ireland. Quaternary Science Reviews 16, 779-791.

Moorman, B.J., Robinson, S.D., Burgess, M.M., 2003. Imaging periglacial conditions with ground-penetrating radar. Permafrost and Periglacial Processes 14, 319-329.

Neal, A., 2004. Ground Penetrating Radar and its use in sedimentology: principles, problems and progress. Earth-Science Reviews 66, 261-330.

Neal, A., Richards, J., Pye, K., 2002. Structure and development of shell cheniers in Essex, southeast England, investigated using high-frequency ground-penetrating radar. Marine Geology 185, 435-469.

Palacky, G.J., 1987. Resistivity characteristics of geologic targets. In: Nabighian, M.N. (Ed.), Electromagnetic Methods in Applied Geophysics Theory, vol. 1. Society of Exploration Geophysicists, Tulsa, Okla., pp. 53-129.

Pellicer, X.M., 2010, Geophysical Characterisation and Evolutionary Model of the Quaternary sediments in the North Offaly region of Central Ireland. Unpublished Ph.D Thesis, Department of Geography, National University of Ireland, Maynooth.

Reynolds, J.M., 1997. An Introduction to Applied and Environmental Geophysics. John Wiley and Sons Ltd.

Slater, L., Reeve, A., 2002. Understanding peatland hydrology and stratigraphy using integrated electrical geophysics. Geophysics 67, 365-378.

Smith, D.G., Jol, H.M., 1992. Ground-penetrating radar investigation of a Lake Bonneville delta, Provo level, Bingham City, Utah. Geology 20, 1083-1086.

Smith, D.G., Jol, H.M., 1995. Ground penetrating radar: antenna frequencies and maximum probable depths of penetration in Quaternary sediments. Journal of Applied Geophysics 33, 93-100.

Stolt, R.H., 1978. Migration by Fourier Transform. Geophysics 43, 23-48.

Trafford, A., 2009. Mapping thickness of raised peat bog deposits using GPR. Near Surface 2009 - 15th European Meeting of Environmental and Engineering Geophysics, Dublin, Ireland.

Turesson, A., 2006. Water content and porosity estimated from ground-penetrating radar and resistivity. Journal of Applied Geophysics 58, 99-111.

Ulriksen, C.P., 1982. The application of impulse radar to civil engineering. Unpubl. PhD thesis, Univ. Lund.

Vanneste, K., Verbeeck, K., Petermans, T., 2008. Pseudo-3D imaging of a low-sliprate, active normal fault using shallow geophysical methods; the Geleen Fault in the Belgian Maas River valley. Geophysics 73 (1), B1-B9.

Warren, W.P., 1992. Drumlin orientation and the pattern of glaciation in Ireland. Sveriges Geologiska Undersokning, Research Papers, Series Ca 81, 359-366.

Warren, W.P., Ashley, G.M., 1994. Origins of the ice-contact stratified ridge (eskers) of Ireland. Journal of Sedimentary Research A64, 433-449.

Wisen, R., Auken, E., Dahlin, T., 2005. Combination of 1D laterally constrained inversion and 2D smooth inversion of resistivity data with a priori data from boreholes. European Association of Geoscientists \& Engineers, Near Surface Geophysics 3, 71-79. 